\title{
Protein expression pattern in response to ionizing radiation in MCF-7 human breast cancer cells
}

\author{
SAMIL JUNG ${ }^{1 *}$, SOONDUCK LEE $^{1 *}$, JAYHEE LEE $^{1-3^{*}}$, CHENGPING LI $^{1}$, JI-YEON OHK $^{1}$, \\ HYEON-KYUNG JEONG ${ }^{1}$, SEUNGKYU LEE ${ }^{2}$, SANGWOO KIM ${ }^{2}$, YUNYEONG CHOI ${ }^{2}$, \\ SUNGHAK KIM ${ }^{2}$, HEUNGWOO LEE ${ }^{2}$ and MYEONG-SOK LEE ${ }^{1 *}$ \\ ${ }^{1}$ Research Center for Women's Diseases, Sookmyung Women's University; ${ }^{2}$ Seoul Science High School, Seoul; \\ ${ }^{3}$ Department of Chemistry, Pohang University of Science and Technology, Pohang, Republic of Korea
}

Received July 29, 2011; Accepted September 26, 2011

DOI: $10.3892 / \mathrm{ol} .2011 .444$

\begin{abstract}
Breast cancer is one of the most common types of cancer in women and is highly treatable by radiotherapy. However, repeated exposure to radiation results in tumor cell resistance. Understanding the molecular mechanisms involved in the response of tumors to $\gamma$-irradiation is important for improving radiotherapy. For this reason, we aimed to identify radiation-responsive genes at the protein level. In the present study, we observed differentially expressed proteins using 2D-PAGE and MALDI-TOF-MS for the global analysis of protein expression patterns in response to ionizing radiation (IR). When the expression patterns of proteins were compared to a control gel, numerous spots were found that differed greatly. Among them, 11 spots were found to be significantly different. One set of proteins (GH2, RGS17, BAK1, CCNH, TSG6, RAD51B, IGFBP1 and CASP14) was upregulated and another set of proteins (C1QRF, PLSCR2 and p34 ${ }^{\text {SEI-I }}$ ) was downregulated after exposure to $\gamma$-rays. These proteins are known to be related to cell cycle control, apoptosis, DNA repair, cell proliferation and other signaling pathways.
\end{abstract}

\section{Introduction}

Breast cancer is a common malignancy and a leading cause of death in women throughout the the world. Radiotherapy is considered crucial treatment for most common types of cancer and is usually used in conjunction with chemotherapy, hormone therapy or surgery. Radiation is known to activate multiple signaling pathways, causing cancer cells to become

Correspondence to: Professor Myeong-Sok Lee, Division of Biological Science and Research Center for Women's Diseases, Sookmyung Women's University, Seoul 140-742, Republic of Korea E-mail: mslee@sookmyung.ac.kr

*Contributed equally

Abbreviations: IR, ionizing radiation

Key words: breast cancer, ionizing radiation, 2D-PAGE inactivated and resulting in diverse types of stress responses, including apoptosis, cell cycle arrest, senescence and gene induction. However, a large number of tumors fail to respond to radiotherapy as they become less sensitive or more resistant to radiation after consecutive treatments. Various studies on the molecular mechanisms of resistance to radiotherapy have been carried out. However, obstacles related to overcoming this resistance remain to be solved. Therefore, identification of the radiation-responsive genes may aid to better understand the molecular mechanisms involved in the response of tumors to radiation and, ultimately, improve radiotherapy.

A number of aspects of the initial response to radiationinduced DNA damage have been extensively analyzed via p53 and other DNA damage checkpoint responses $(1,2)$. For example, the tumor suppressor gene TP53 ( $p 53$ ) plays a significant role in the cellular response to radiation-induced stress (3-5). In cells carrying a non-functional $p 53$, cell-cycle arrest and DNA repair cannot occur. This increases the level of genomic instability and allows tumor growth despite the exposure to radiation (4-6). In addition, a number of radiationresponsive genes are identified through different approaches. Various stress-responsive effector genes have been known to be inducible by radiation (7-11). The major effector genes identified in the radiation-induced response include $R A F 1$, CDKNIA (p21), GADD45A (GADD45), 14-3-3 o (a member of the YWHA family), BAX, TNFRSF (Fas/APO1), TNFRSF 10B (KILLER/DR5), PIG, THBSI (TSPI), IGFBP3 and DIR1. These radiation-responsive effector genes and their control factors play key roles in the cellular response to radiationinduced stress by modulating cell cycle checkpoints, apoptosis and DNA repair, which enhance cell survival (3,8-10,12-16). Changes in the mRNA expression levels were reported by cDNA microarray data targeting radiation-responsive genes in human breast cancer cells (17-21). In addition, Kis et al identified radiation-responsive genes using a microarray analysis in primary human fibroblasts (22). These authors detected approximately 200 ionizing radiation (IR) responsive genes at the transcriptional level, of which 30 (28 up- and 2 downregulated) responded to radiation in all investigated cells and 20 were grouped according to function: DNA damage response (GADD45A, BTG2, PCNA and IER5), regulation of the cell cycle and cell proliferation (CDKN1A, PPM1D, 
SERTAD1, PLK2, PLK3 and CYR61), programmed cell death (BBC3 and TP53INP1), signaling pathways (SH2D2A, SLIC1, GDF15, and THSD1), and other functions (SEL10, FDXR, CYP26B1 and OR11A1) (22). However, the mRNA expression profiles did not match their protein expression profiles as the radiation-responsive genes appeared to respond differently at the transcriptional and protein levels. Moreover, the molecular mechanisms inactivating tumor cells in response to radiation have yet to be elucidated, although several mechanisms are known to be involved in this process. We, therefore, aimed to identify the radiationresponsive genes at the protein level using two-dimensional polyacrylamide gel electrophoresis (2D-PAGE) and matrix assisted laser desorption/ionization time of flight-mass spectrometry (MALDI-TOF-MS) in MCF-7 human breast cancer cells. Tools such as 2D-PAGE and MALDI-TOF-MS have been widely used for the study of cancer proteomics, as noted in several other studies (23-25).

In this study, a global analysis of the protein expression pattern was performed using 2D-PAGE and MALDI-TOF-MS to identify radiation-responsive proteins in $\mathrm{MCF}-7$ breast cancer cells.

\section{Materials and methods}

Condition of the MCF-7 cell culture and treatment of ionizing radiation (IR). The MCF-7 human breast cancer cell line was purchased from the American Type Culture Collection (ATCC, Manassas, VA, USA). MCF-7 cells were cultured at $37^{\circ} \mathrm{C}$ in a humidified atmosphere composed of $95 \%$ air and $5 \% \mathrm{CO}_{2}$ in Dulbecco's modified Eagle's medium (DMEM) (WelGENE Inc., Daegu-si, Korea). This medium was supplemented with $10 \%$ fetal bovine serum (Gibco BRL, Seoul, Korea) and $1 \%$ antibiotic-antimycotic (Gibco BRL). To induce an IR response, the MCF-7 cells were irradiated with $\gamma$-rays with a ${ }^{137} \mathrm{Cs} \gamma$-ray source (Atomic Energy of Canada, Ltd., Ontario, Canada). The cells were harvested after the indicated time of incubation at $37^{\circ} \mathrm{C}$. Cell viability was assessed by a trypan blue exclusion test.

Protein extraction. Cells were washed with cold phosphatebuffered saline (PBS) and centrifuged at 3,000 rpm, $4^{\circ} \mathrm{C}$ for $3 \mathrm{~min}$. The centrifuged cells were resuspended with lysis buffer [500 mM HEPES (pH 8.5), 4\% CHAPS, 8 M urea, $1 \mu \mathrm{g} / \mathrm{ml}$ aprotinin, $100 \mu \mathrm{g} / \mathrm{ml} \mathrm{PMSF}$, and $2.4 \mathrm{mg} / \mathrm{ml}$ DTT], sonicated for $10 \mathrm{sec}(5 \mathrm{X})$ on ice, and then centrifuged at 13,000 rpm, at $4^{\circ} \mathrm{C}$ for $10 \mathrm{~min}$. The concentrations of the protein samples were determined using a modified Bradford protein assay (Bio-Rad, Hercules, CA, USA).

2D-PAGE, gel scanning and image analysis. The first dimensional isoelectric focusing (IEF) was performed on precast $18 \mathrm{~cm}$ immobilized $\mathrm{pH}$ 3.0-10.0 gradient (IPG) strips (Amersham Pharmacia Biotech) at $20^{\circ} \mathrm{C}$ using a commercial flatbed electrophoresis system (IPGphor; Amersham Pharmacia Biotech). Proteins of $500 \mu \mathrm{g}$ were mixed with a rehydration buffer containing $8 \mathrm{M}$ urea, $2 \%$ (w/v) CHAPS, $2.4 \mathrm{mg} / \mathrm{ml} \mathrm{DTT}, 2 \%$ (v/v) IPG buffer, and a trace of bromophenol blue as a tracking dye. The mixtures were loaded onto an IPG strip, followed by $12 \mathrm{~h}$ of active rehydration at $50 \mathrm{~V}$ and
$50 \mu \mathrm{A}$, which was ramped to $500 \mathrm{~V}$ and $50 \mu \mathrm{A}$ over a period of $10 \mathrm{~min}$. It was then maitained at $5000 \mathrm{~V}$ and $50 \mu \mathrm{A}$ for $1 \mathrm{~h}$. At the end of the first dimension run $(80 \mathrm{kV} \bullet \mathrm{h})$, the IPG strips were immediately loaded onto $11 \%$ SDS-PAGE gels and held in place with $0.5 \%$ agarose dissolved in a SDS-PAGE running buffer. In the second dimension, SDS-PAGE was performed for separation without a stacking gel at $150 \mathrm{~V}$, and $20 \mathrm{~mA}$ for $20 \mathrm{~h}$ per gel in a SDS-electrophoresis buffer (25 mM Tris, $92 \mathrm{mM}$ glycine and $0.1 \%$ SDS). After electrophoresis separation, the gels were stained using Bio-Rad Silver Stain kit (catalog no. 161-0443). The stained 2-D gels were scanned on a Las-3000 (Fuji Photo Film Co.) using 2-D software PDQuest (Bio-Rad). The different gel patterns were then automatically matched to each other and the quantities of the matched spots in the different gels were compared. The molecular masses and $\mathrm{pI}$ values were calculated with the PDQuest software using the selected $\mathrm{pI}$ and $\mathrm{Mr}$ standard proteins.

Matrix-assisted laser desorption/ionization-time of flightmass spectrometry (MALDI-TOF-MS). Proteins from the gels were identified by MALDI-TOF-MS. After tryptic in-gel digestion of 2D-PAGE resolved proteins, samples for MALDI peptide mass mapping were prepared, as previously described (26). Mass spectra were obtained using a Voyager-DE STR MALDI-TOF mass spectrometer (Applied Biosystems, Cambridge, MA, USA). The proteins were identified according to their tryptic peptide mass fingerprint after a database search was performed on MS-Fit, which is accessible over the World Wide Web at http://prospector.ucsf.edu/. MS-Fit performed a rapid database search by comparing experimentally determined masses from the proteolytic digestion of proteins with peptide database masses calculated from the NCBInr protein database and Swiss-Prot accession numbers.

Cell cycle analysis by fluorescence-activated cell sorting $(F A C S)$. For a FACS analysis, cells were harvested at the indicated time points, washed twice in ice-cold PBS, and fixed by resuspending them in absolute ethanol for $30 \mathrm{~min}$. The fixed cells were centrifuged at 1,500 rpm for $5 \mathrm{~min}$ and washed twice with cold PBS. The cell pellets were resuspended in $0.5 \mathrm{ml}$ of PBS containing $50 \mu \mathrm{g} / \mathrm{ml}$ propidium iodide (Sigma-Aldrich Chemical Co., Korea), 10\% sodium citrate (Sigma), $100 \mu \mathrm{g} /$ ml RNase (Invitrogen, Korea), and $0.001 \%$ NP40 (Sigma). Following their incubation at $37^{\circ} \mathrm{C}$ for $30 \mathrm{~min}$ in the dark, the samples were analyzed by a FACScan flow cytometer (BectonDickinson FACScan, Sunnyvale, CA, USA) equipped with the CellQuest 3.2 software (Becton-Dickinson).

\section{Results}

G2 cell cycle arrest induced by IR in MCF-7 cells. MCF-7 cells were irradiated with different doses of $\gamma$-radiation of 1 , 5,10 , or $20 \mathrm{~Gy}$, in which the cell growth was repressed in the cells exposed to $20 \mathrm{~Gy}$ of radiation, as shown in Fig. 1A. The IR treatment of the MCF-7 cells did not affect cell viability, as assessed by the trypan blue exclusion test (data not shown). Instead, the cell growth was repressed due to cell cycle arrest at the G2 phase, as revealed in the FACS analysis (Fig.1B). This result suggests that IR-irradiated MCF-7 cells undergo cell cycle arrest rather than apoptosis. These data are consis- 
Table I. Standard proteins identified by MALDI-TOF-MS.

\begin{tabular}{llll}
\hline AN $^{\mathrm{a}}$ & Gene & Protein & $\mathrm{pI} / \mathrm{Mw}(\mathrm{Da})$ \\
\hline $\mathrm{P} 02545$ & LMNA & Lamin A/C & $6.6 / 74140$ \\
Q08209 & PPP3CA & Serine/threonine protein phosphatase & $5.6 / 58688$ \\
& & 2B catalytic subunit, $\alpha$ isoform & $6.4 / 36927$ \\
P31942 & HNRPH3 & Heterogeneous nuclear ribonucleoprotein H3 & $6.5 / 29443$ \\
Q8N1Q1 & CA13 & Carbonic anhydrase XIII & $8.8 / 27235$ \\
Q13886 & BTEB1 & Transcription factor BTEB1 & $4.7 / 24703$ \\
Q9NY72 & SCN3B & Sodium channel $\beta$-3 subunit & $3.9 / 18903$ \\
20977872 & ZFX & X-linked zinc finger protein & $7.7 / 18013$ \\
P05092 & PPIA & Peptidyl-prolyl cis-trans isomerase A & $5.5 / 10309$ \\
Q9H503 & $C 20 O R F 179$ & Hypothetical BAF-like protein C20orf179 & \\
\hline
\end{tabular}

${ }^{\mathrm{a}} \mathrm{AN}$, Swiss-Prot accession number (AN) from the Swiss-Prot database. ${ }^{\mathrm{b}}$ Accession number is from the NCBInr protein database.

A

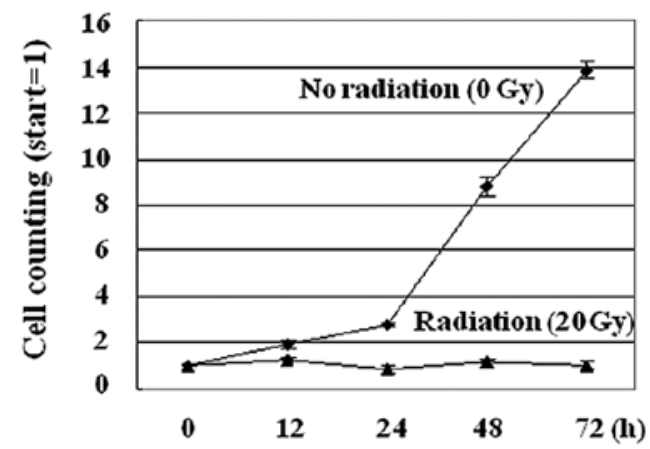

$\mathbf{B}$

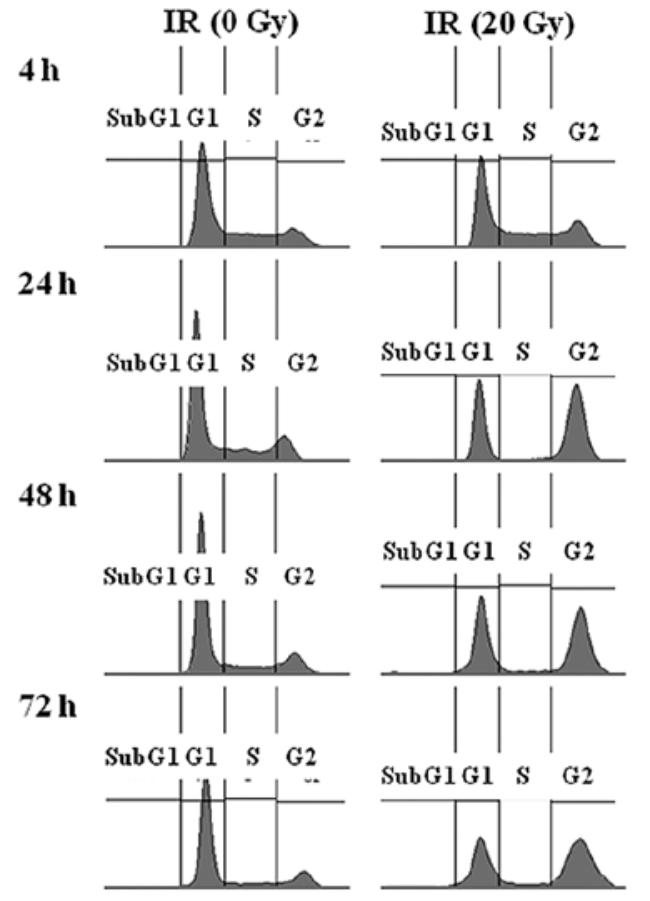

Figure 1. Ionizing radiation (IR)-induced cell cycle arrest at the G2 phase in MCF-7 cells. (A) Cell growth analysis of MCF-7 cells in response to IR MCF-7 cells were exposed to $20 \mathrm{~Gy}$ of IR, incubated for the indicated times, and the growth rate was then checked. (B) FACS analysis of MCF-7 cells either untreated or treated with 20 Gy of IR. One of the three representative experiments is shown. tent with previous studies in which IR induced cell cycle arrest but failed to activate the mitochondrial death pathway in MCF-7 cells (27). Thus, to establish the genes responsible for this phenotype we aimed to identify the radiation-responsive proteins in MCF-7 cells.

Identification of radiation-responsive genes in MCF-7 cells. To obtain information on the expression profile of radiationinduced and reduced protein, MCF-7 breast cancer cells were irradiated with $20 \mathrm{~Gy}$ of $\gamma$-rays and harvested after incubation for $0,4,12,24$ or $48 \mathrm{~h}$. We then observed differentially expressed proteins using 2D-PAGE and MALDI-TOF-MS as described in Materials and methods. Proteins with approximately 1,000-1,200 spots in each gel were visualized by silver staining and detected by PDQuest 2D-image-analysis software (Bio-Rad). After the spot detection, the gels were matched to each other, with the aid of the so-called landmark function, and approximately 730 spots in total were matched in all gels analyzed according to the PDQuest software. For internal standards, 9 spots were chosen randomly to calculate the deviation of the spot position and identified by MALDI-TOF-MS. These identified proteins included LMNA, PPP3CA, HNRPH3, CA13, BTEB1, SCN3B, ZFX, PPIA and C20ORF179 (Fig. 2 and Table I), and were used for the generation of a relevant $\mathrm{pI}$ and $\mathrm{Mr}$ scale for the entire pattern.

When the expression patterns of proteins were compared to the control gel, numerous spots were found to differ greatly from one another. Among them, 11 spots were found to be significantly different. One set of proteins was upregulated in response to IR in the MCF-7 cells. These proteins included RAD51B, CCNH, TSG6, GH2, RGS17, BAK1, IGFBP1 and CASP14 (Table II). Fig. 3 shows the regions containing upregulated proteins, which are marked by black rectangles and are magnified on the lower gels. All of these proteins showed a similar pattern in terms of the protein expression level. The expression level of each protein started to increase after exposure to $\gamma$-rays (Fig. 3A-C). Most of these proteins are known to be involved in the cellular processes of cell cycle control, apoptosis, DNA repair, cell proliferation, and other functions. 
A
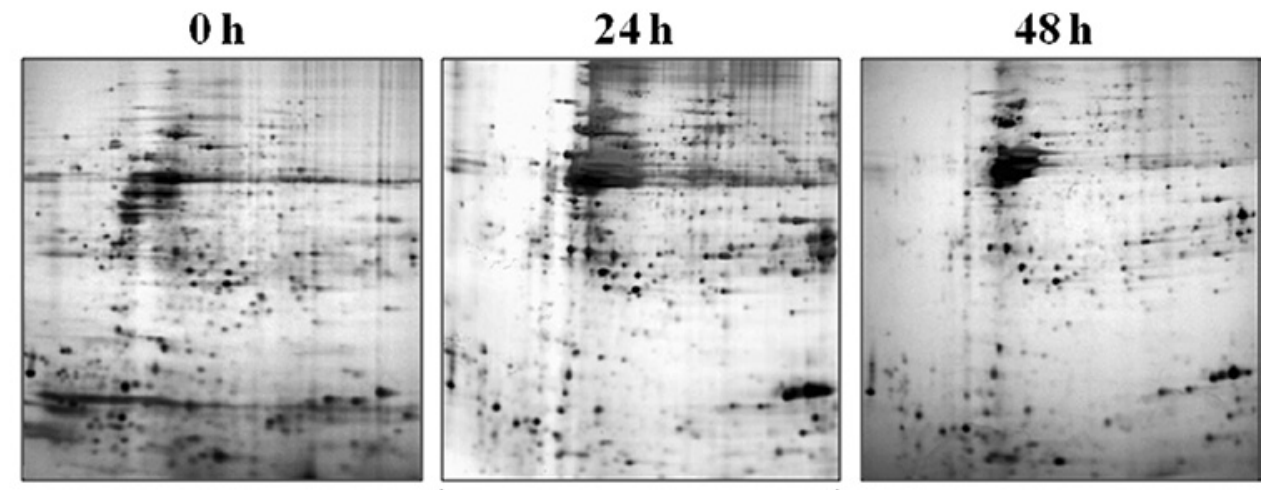

B

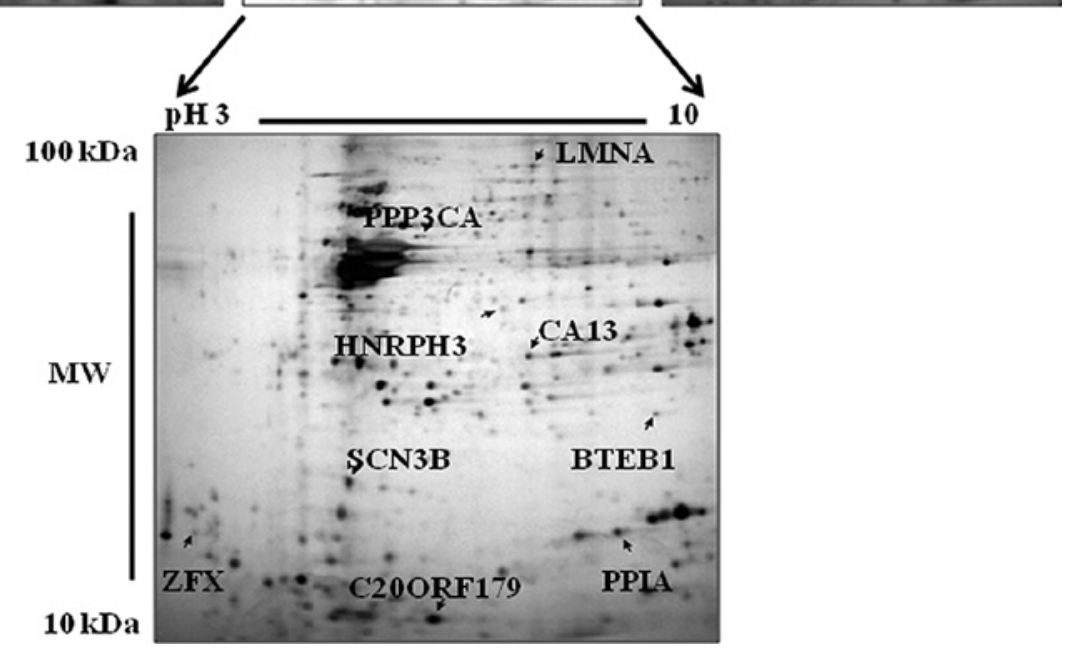

Figure 2. Position and identification of the selected standard proteins in the silver-stained 2-D gels. (A) MCF-7 cells were treated with 20 Gy of IR and incubated for the indicated times. The proteins are shown as a silver-stained image. (B) The standard protein spots are shown in an enlarged gel. More specific information regarding the spots is provided in Table I. The horizontal axis is the isoelectric focusing dimension, which stretches from $\mathrm{pH} 3.0$ (left) to $\mathrm{pH} 10.0$ (right). The vertical axis is the polyacrylamide gel dimension, which stretches from $10 \mathrm{kDa}$ (bottom) to $100 \mathrm{kDa}$ (top).

A

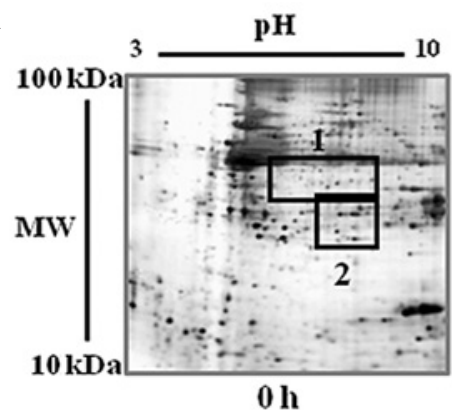

0l
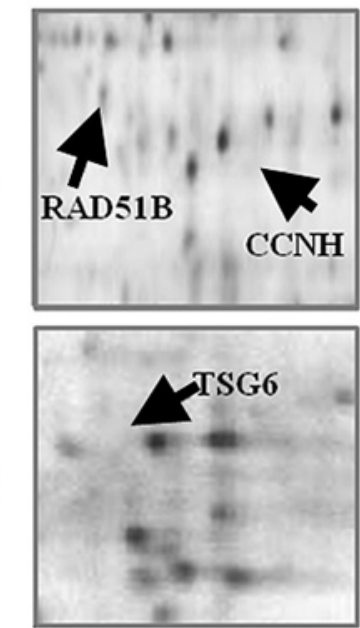

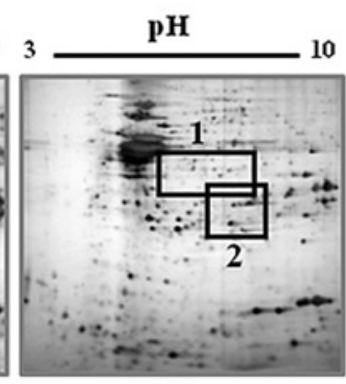

$12 \mathrm{~h}$
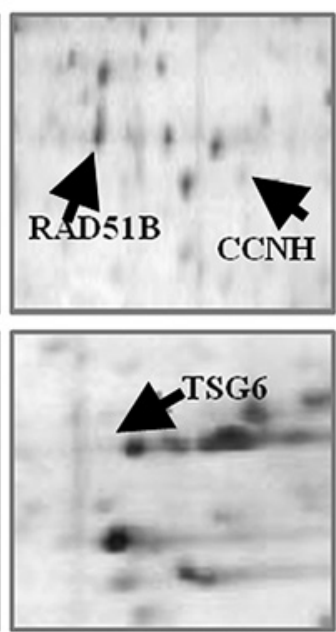

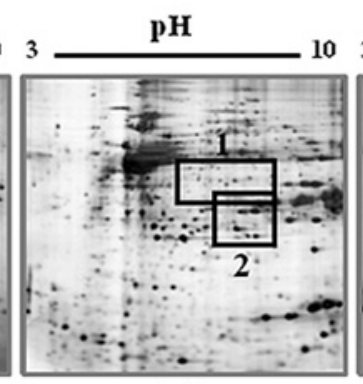

$24 \mathrm{~h}$
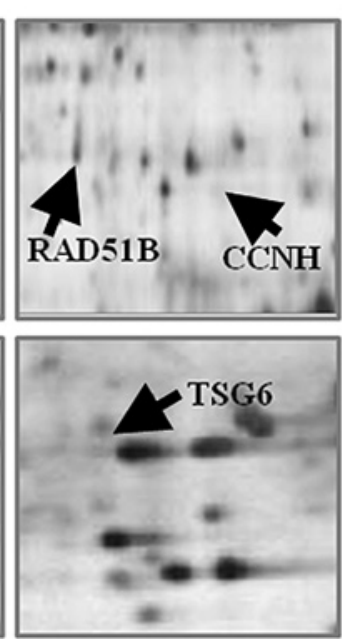
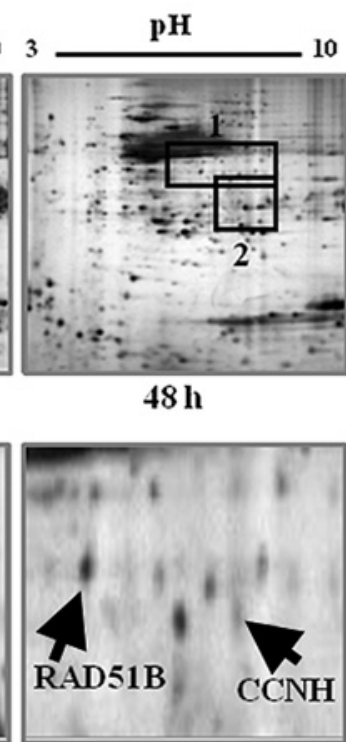

$48 \mathrm{~h}$

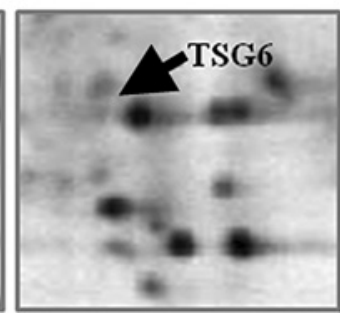


B
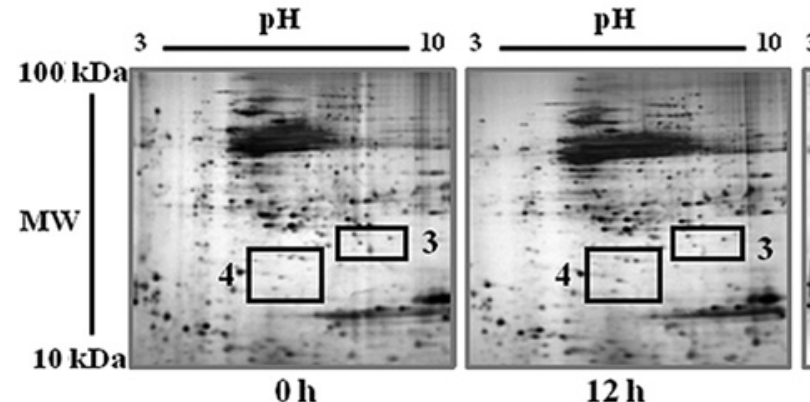

$12 \mathrm{~h}$
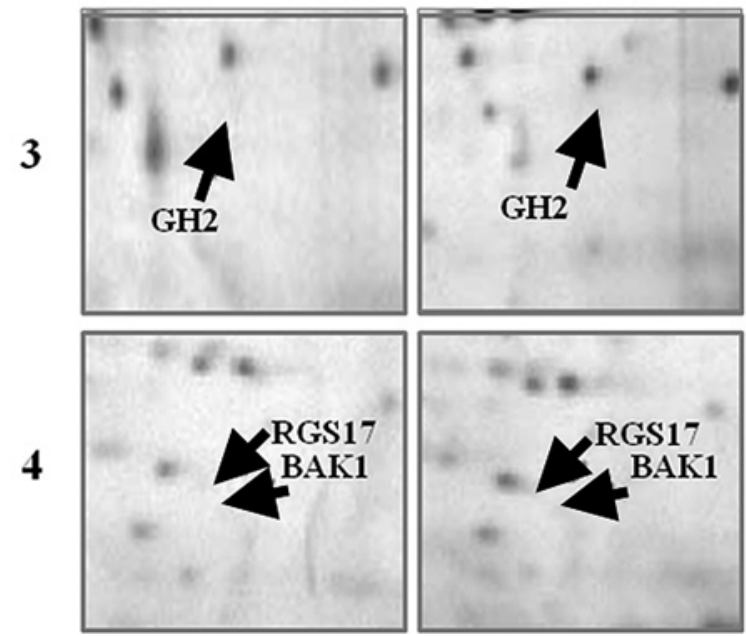
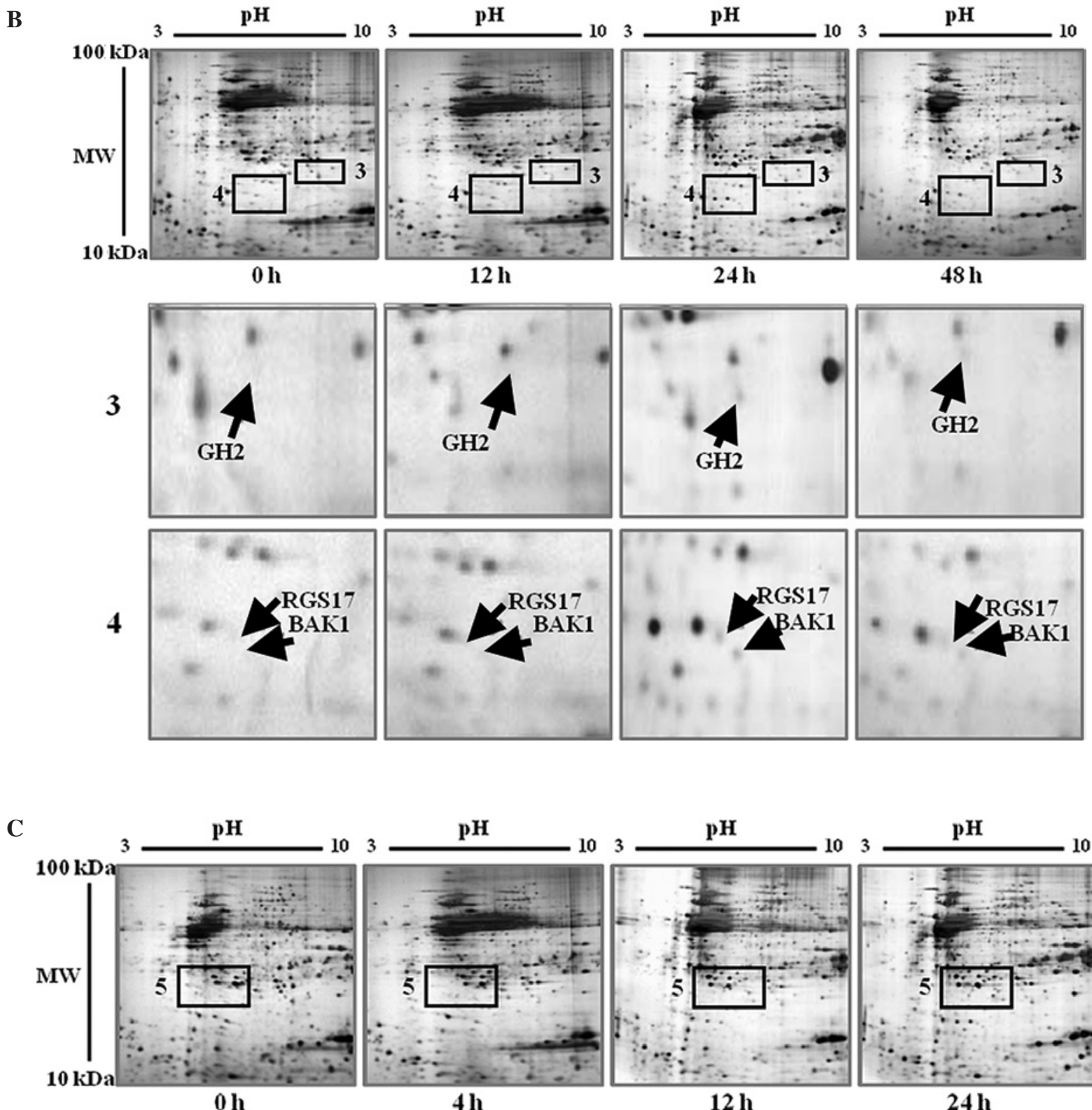

103
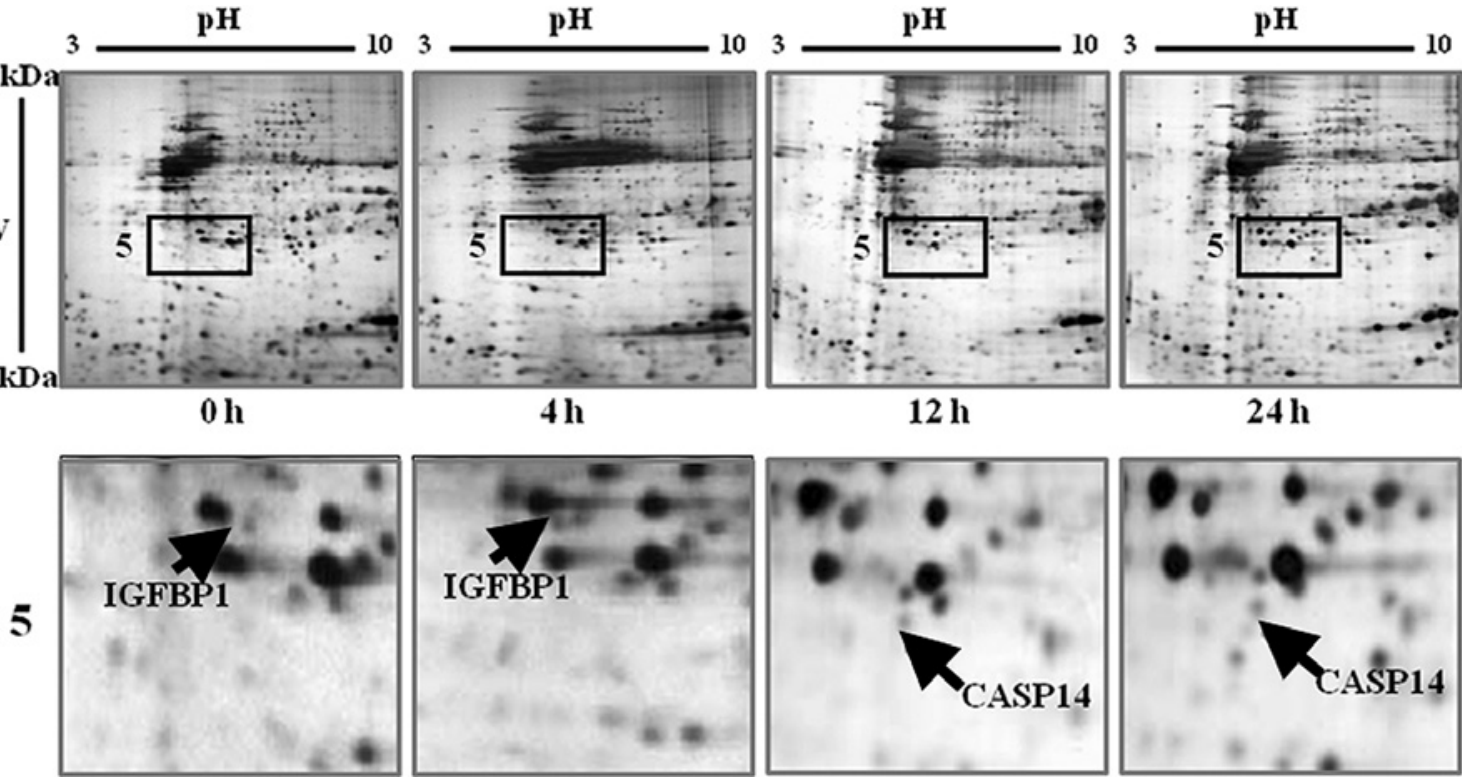

Figure 3. Up-regulated proteins following exposure to ionizing radiation (IR). MCF-7 cells were treated with 20 Gy of IR and incubated for the indicated times. The proteins are shown as a silver-stained image. The horizontal axis is the isoelectric focusing dimension, which stretches from pH 3.0 (left) to $\mathrm{pH} 10.0$ (right). The vertical axis is the polyacrylamide gel dimension, which stretches from $10 \mathrm{kDa}$ (bottom) to $100 \mathrm{kDa}$ (top). In the uppermost panels, protein expression patterns are shown, in which the black rectangles of the upper gels include upregulated protein spots. In the lower enlarged gels, upregulated proteins are indicated with the arrows on the enlarged gels, which show the differences more clearly. Differentially expressed protein spots identified by peptide mass fingerprinting are labeled here with the protein name. More specific information about the spots (A) RAD51B, CCNH and TSG6; (B) GH2, RGS17 and BAK1; and (C) IGFBP1 and CASP14 is provided in Table II.

In another set, the expression levels of three proteins were downregulated following exposure to $\gamma$-rays. They include C1QRF, PLSCR2 and p34 $4^{\text {SEI-1 }}$. These proteins are marked by black rectangles on the gels and are magnified on the lower gels (Fig. 4). In the percentage volume of the spots compared between 0 and $48 \mathrm{~h}$ using the PDQuest software, a considerable amount of each protein was detected in the control gel $(0 \mathrm{~h})$. The C1QRF and PLSCR2 
Table II. Differentially expressed proteins in response to IR in MCF-7 cells.

\begin{tabular}{lllll}
\hline Class & AN & Gene & Protein & $\mathrm{pI} / \mathrm{Mw}(\mathrm{Da})$ \\
\hline Class I & \multicolumn{2}{c}{ (Upregulated proteins in response to IR in MCF-7 cells) } \\
& O15315 & RAD51B & DNA repair protein RAD51 homolog 2 (R51H2) & $5.8 / 38257$ \\
& P51946 & $C C N H$ & Cyclin H & $6.7 / 37644$ \\
& P98066 & $T S G 6$ & Tumor necrosis factor-inducible protein TSG-6 & $6.5 / 31232$ \\
& P01242 & $G H 2$ & Growth hormone variant & $7.6 / 25000$ \\
& Q9UGC6 & $R G S 17$ & Regulator of G-protein signaling 17 & $5.6 / 24360$ \\
& Q16611 & BAK1 & Bcl-2 homologous antagonist/killer & $5.7 / 23409$ \\
& P08833 & $I G F B P 1$ & Insulin-like growth factor binding protein 1 & $5.1 / 27904$ \\
& P31944 & $C A S P 14$ & Caspase-14 & $5.4 / 27680$
\end{tabular}

Class II (Downregulated proteins in response to IR in MCF-7 cells)

$\begin{array}{llll}\text { O75973 } & \text { C1QRF } & \text { C1q-related factor } & 5.3 / 26453 \\ \text { Q9NRY7 } & \text { PLSCR2 } & \text { Phospholipid scramblase 2 } & 5.5 / 25523 \\ \text { Q9UHV2 } & p 34^{\text {SEI-1 }} & \text { cycline-dependent kinase 4 (cdk4)-binding protein } & 4.3 / 24674\end{array}$

${ }^{\mathrm{a}} \mathrm{AN}$, Swiss-Prot accession number (AN) from the Swiss-Prot database. ${ }^{\mathrm{b}} \mathrm{pI}$ and Molecular weights were calculated using PDQuest software by utilizing the selected $\mathrm{pI}$ and $\mathrm{Mr}$ standard proteins.

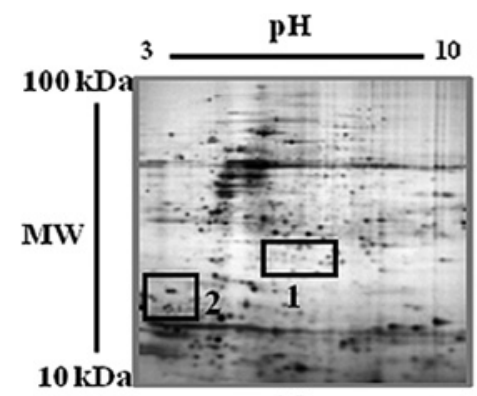

$0 \mathbf{h}$
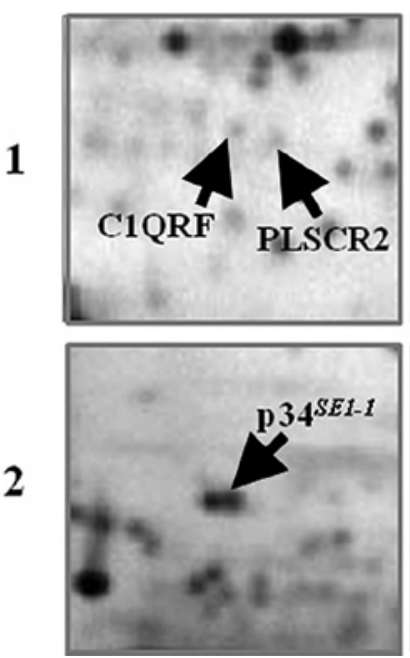

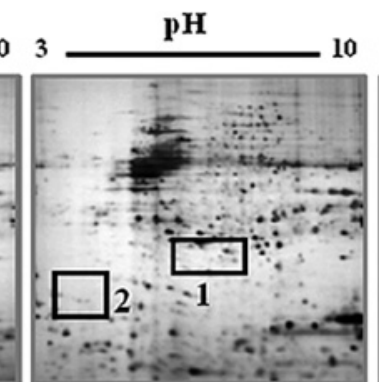

$4 \mathrm{~h}$
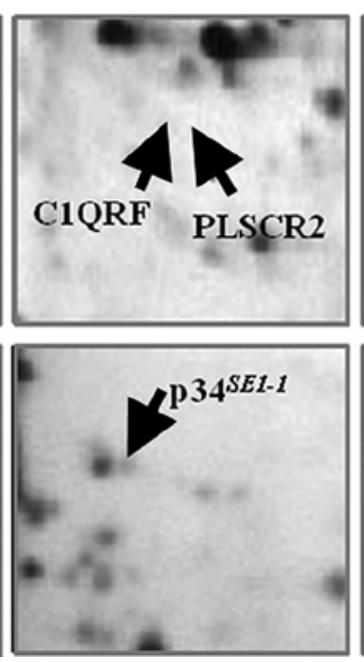

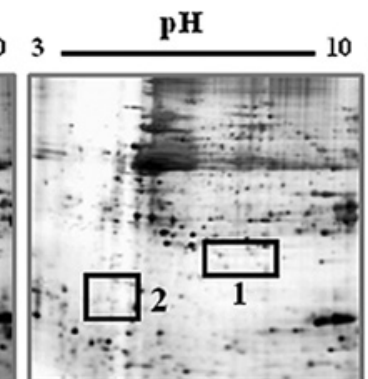

$24 h$
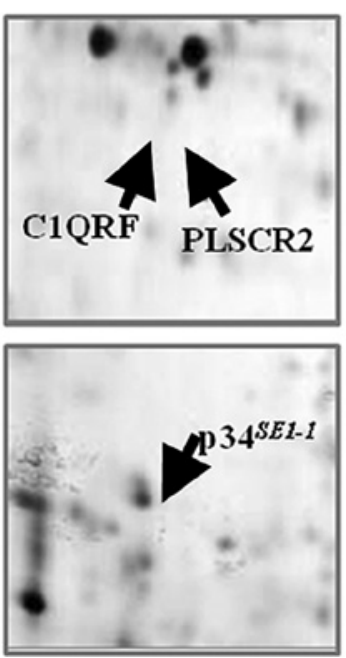

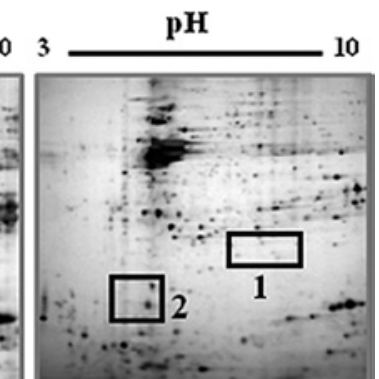

$48 \mathrm{~h}$
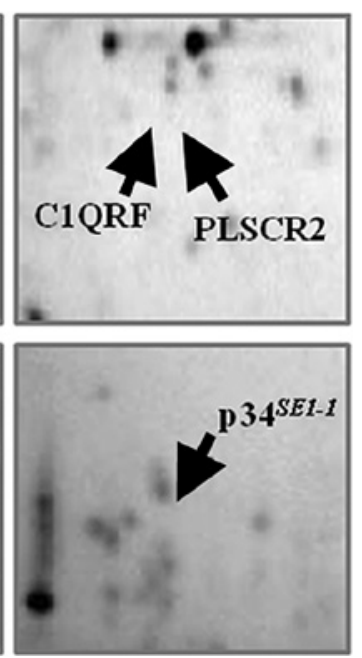

Figure 4. Downregulated proteins following exposure to ionizing radiation (IR). MCF-7 cells were treated with 20 Gy of IR and incubated for the indicated times. The proteins are shown as a silver-stained image. In the upper panels, the regions containing downregulated proteins are indicated with the black rectangles. In the lower enlarged gels, downregulated proteins are indicated with the arrows. More specific information about the spots C1QRF, PLSCR2 and $\mathrm{p} 34^{\text {SEI-I }}$ is provided in Table II.

proteins were found only at $0 \mathrm{~h}$ and $\mathrm{p} 34^{\text {SEI-I }}$ was detected at 0 and $4 \mathrm{~h}$. However, their expression levels started to decrease from $12 \mathrm{~h}$ and were significantly downregulated after $48 \mathrm{~h}$ (Fig. 4).

\section{Discussion}

In this study, we observed up- and downregulated proteins in the MCF-7 breast cancer cell line. The proteins maintained 
at an elevated level in the radiation-derived MCF-7 cells are correlated to cell cycle control, apoptosis, DNA repair, and cell proliferation. The genes responsible for this elevation include: $R A D 51 B$, which encodes a DNA repair protein RAD51 homolog 2 , which is involved in the homologous recombination repair (HRR) pathway of double-stranded DNA breaks arising during DNA replication or induced by DNA-damaging agents (28). CCNH encodes cyclin $\mathrm{H}$, which regulates CDK7, the catalytic subunit of the CDK-activating kinase (CAK) enzymatic complex. It is involved in cell cycle control and RNA transcription by RNA polymerase II. Its expression and activity are constant throughout the cell cycle (29). TSG6 encodes the tumor necrosis factor-inducible protein TSG-6. This gene may be involved in cell-cell and cell-matrix interactions during inflammation and tumorigenesis (30). GH2 encodes a growth hormone variant that plays an important role in growth control and stimulates the proliferation of human MCF-7 mammary carcinoma cells by activating the MAPK signaling pathway (31). RGS17 encodes a regulator of G-protein signaling 17 that inhibits signal transduction by increasing the GTPase activity of $\mathrm{G}$ protein $\alpha$ subunits thereby driving them into their inactive GDP-bound form. RGS17 plays important roles in T-cell proliferation and IL-2 production and RGS17 deficiency leads to impaired T-cell activation (32). BAK1 encodes a Bcl-2 homologous antagonist/killer that has been reported to be regulated by p53 (33). It induces cell death and accelerated apoptosis (34-36). IGFBP1 encodes insulin-like growth factor binding protein 1 . IGFBP1 is expressed in the breast both in vitro and in vivo $(37,38)$. The upregulation of IGFBP1 is associated with the malignant transformation of breast tissue (38). CASP14 encodes caspase-14 which is involved in the death receptor and granzyme B apoptotic pathways. It may function as a downstream signal transducer of cell death (39).

On the other hand, protein expression levels for C1QRF, PLSCR 2 and $\mathrm{p} 34^{S E I-1}$ were decreased. The genes responsible in this case include: $C 1 Q R F$, which encodes a Clq-related factor containing one Clq domain that is a component of the complement pathway, and is involved in tumor cytotoxicity (40). Moreover, PLSCR 2 encodes phospholipid scramblase 2, which plays a central role in the recognition of apoptotic and injured cells by the reticuloendothelial system (41). p3 $4^{\text {SEI-1 }}$ encodes a transcriptional regulator interacting with PHD-bromodomain 1 (Trip-Br1), which renders the activity of cyclin D1/CDK4 resistant to the inhibitory effects of p16 ${ }^{\mathrm{INK} 4 \mathrm{a}}$. In addition, p16 ${ }^{\mathrm{INK} 4 \mathrm{a}}$ specifically binds and inhibits CDK4, the partner kinase of the D1 cyclin strongly implicated in the phosphorylation of $\mathrm{pRb}$ and thereby in G1/S control (42-44). The decreased expression of the p34 ${ }^{\text {SEI-1 }}$ protein may be related to the induction of cell cycle arrest at the $\mathrm{G} 2$ phase in MCF-7 cells.

In conclusion, our study may aid in better understanding the molecular mechanism that responds to radiation in cancer cells. Additionally, our findings may contribute to the development of more effective ways of combining radiation therapy with other systemic therapies.

\section{References}

1. El-Deiry WS: The role of p53 in chemosensitivity and radiosensitivity. Oncogene 22: 7486-7495, 2003.
2. Iliakis $\mathrm{G}$, Wang $\mathrm{Y}$, Guan J and Wang $\mathrm{H}$ : DNA damage checkpoint control in cells exposed to ionizing radiation. Oncogene 22: 5834-5847, 2003.

3. Amundson SA, Myers TG and Fornace Jr: Roles for $\mathrm{p} 53$ in growth arrest and apoptosis: Putting on the brakes after genotoxic stress. Oncogene 17: 3287-3299, 1998.

4. Fornace AJ Jr, Amundson SA, Bittner M, Myers TG, Meltzer P, Weinsten JN and Trent J: The complexity of radiation stress reponse: analysis by informatics and functional genomics approaches. Gene Expr 7: 387-400, 1999.

5. King TC, Estalilla OC and Safran H: Role of p53 and p16 gene alterations in determining response to concurrent paclitaxel and radiation in solid tumor. Semin Radiat Oncol 9: 4-11, 1999.

6. Lu X, Lane DP: Differential induction of transcriptionally active p53 following UV or ionizing irradiation: defects in chromosome instability syndromes? Cell 75: 765-778, 1993.

7. Keyse SM: The induction of gene expression in mammalian cells by radiation. Semin Cancer Biol 4: 119-128, 1993.

8. Iliakis G: Cell cycle regulation in irradiated and nonirradiated cells. Semin Oncol 24: 602-615, 1997.

9. Eckardt Schupp F and Klaus C: Radiation inducible DNA repair processes in eukaryotes. Biochimie 81: 161-171, 1999.

10. Maity A, McKenna WG and Muschel RJ: The molecular basis for cell cycle delays following ionizing radiation: a review. Radiother Oncol 31: 1-13, 1994.

11. Forrester HB, Vidair CA, Albright N, Ling CC and Dewey WC: Using computerized video time lapse for quantifying cell death of Xirradiated rat embryo cells transfected with cmyc or cHaras. Cancer Res 59: 931-939, 1999.

12. Kasid U, Suy S, Dent P, Ray S, Whiteside TL and Sturgill TW: Activation of Raf by ionizing radiation. Nature 382: 813-816, 1996.

13. Waldman T, Lengauer C, Kinzler KW and Vogelstein B: Uncoupling of $\mathrm{S}$ phase and mitosis induced by anticancer agents in cells lacking p21. Nature 381: 713-716, 1996.

14. El-Deiry WS: Regulation of p53 downstream genes. Semin Cancer Biol 8: 345-357, 1998.

15. Robson T, Joiner MC, Wilson GD, McCullough W, Price ME, Logan I, Jones H, McKeown SR and Hirst DG: A novel human stress response-related gene with a potential role in induced radio-resistance. Radiat Res 152: 451-461, 1999.

16. Lowe SW, Schmitt EM, Smith SW, Osborne BA and Jacks T: p53 is required for radiation-induced apoptosis in mouse thymocytes. Nature 362: 847-849, 1993.

17. Honda M, Kaneko S, Kawai H, Shirota Y and Kobayashi K: Differential gene expression between chronic hepatitis B and C hepatic lesion. Gastroenterology 120: 955-966, 2001.

18. Okabe H, Satoh S, Kato T, Kitahara O, Yanagawa R, Yamaoka Y, Tsunoda T, Furukawa Y and Nakamura Y: Genome-wide analysis of gene expression in human hepatocellular carcinomas using cDNA microarray: identification of genes involved in viral carcinogenesis and tumor progression. Cancer Res 61: 2129-2137, 2001.

19. Shirota Y, Kaneko S, Honda M, Kawai HF and Kobayshi K: Identification of differently expressed genes in hepatocellular carcinoma with cDNA microarrays. Hepatology 33: 832-840, 2001.

20. Takeo S, Arai H, Kusano N, Harada T, et al: Examination of oncogene amplification by genomic DNA microarray in hepatocellular carcinomas comparison with comparative genomic hybridization analysis. Cancer Genet Cytogenet 130: 127-132, 2001.

21. Xu XR, Huang J, Xu ZG, et al: Insight into hepatocellular carcinogenesis at transcriptome level by comparing gene expression profiles of hepatocellular carcinoma with those of corresponding noncancerous liver. Proc Natl Acad Sci USA 98: 15089-15094, 2001.

22. Kis E, Szatmari T, Keszei M, Farkas R, Esik O, Lumniczky K, Falus A and Safrany G: Microarray analysis of radiation response genes in primary human fibroblasts. Int $\mathrm{J}$ Radiat Oncol Biol Phys 66: 1506-1514, 2006.

23. Hondermarck H, Vercoutter-Edouart A.-S, Revillion F, Lemoine J, El-Yazidi-Belkoura I, Nurcombe V and Peyrat JP: Proteomics of breast cancer for marker discovery and signal pathway profiling. Proteomics 1: 1216-1232, 2001.

24. Oh JM, Brichory F, Puravs E, Kuick R, Wood C, Rouillard JM, Tra J, Kardia S, Beer D and Hanash S: A database of protein expression in lung cancer. Proteomics 1: 1303-1319, 2001.

25. Stulik J, Hernychova L, Porkertova S, Knižek J, Macela A, Bures J, Jandik P, Langridge JI and Jungblut PR: Proteome study of colorectal carcinogenesis. Electrophoresis 22: 3019-3025, 2001. 
26. Kim W, Oe LS, Kim JS, Ryu YH, Byeon JY, Kim HJ, Kim YI, Heo JS, Park YM and Jung G: Comparison of proteome between hepatitis B virus- and hepatitis $\mathrm{C}$ virus-associated hepatocellular carcinoma. Clin Cancer Res 9: 5493-5500, 2003.

27. Janicke RU, Engels IH, Dunkern T, Kaina B, Schulze-Osthoff K and Porter AG: Ionizing radiation but not anticancer drugs causes cell cycle arrest and failure to activate the mitochondrial death pathway in MCF-7 breast carcinoma cells. Oncogene 20 : 5043-5053, 2001.

28. Albala JS, Thelen MP, Prange C, Fan W, Christensen M, Thompson LH and Lennon GG: Identification of a novel human RAD51 homolog, RAD51B. Genomics 46: 476-479, 1997.

29. Jin K, Nagayama T, Chen J, Stetler AR, Kawaguchi K, Simon RP and Graham SH: Molecular cloning of a cell cycle regulation gene cyclin $\mathrm{H}$ from ischemic rat brain: expression in neurons after global cerebral ischemia. J Neurochem 73: 1598-1608, 1999.

30. Lee TH, Wisniewski HG and Vilcek J: A novel secretory tumor necrosis factor-inducible protein (TSG-6) is a member of the family of hyaluronate binding proteins, closely related to the adhesion receptor CD44. J Cell Biol 116: 545-557, 1992.

31. Kaulsay KK, Mertani HC, Tornell J, Morel G, Lee KO and Lobie PE: Autocrine stimulation of human mammary carcinoma cell proliferation by human growth hormone. Exp Cell Res 250 : 35-50, 1999.

32. Oliveira-dos-Santos AJ, Matsumoto G, Snow BE, et al: Regulation of $\mathrm{T}$ cell activation, anxiety, and male aggression by RGS2. Proc Natl Acad Sci USA 97: 12272-12277, 2000

33. Pearson AS, Spitz FR, Swisher SG, Kataoka M, Sarkiss MG, Meyn RE, McDonnell TJ, Cristiano RJ and Roth JA: Upregulation of the proapoptotic mediators Bax and Bak after adenovirus-mediated p53 gene transfer in lung cancer cells. Clin Cancer Res 6: 887-890, 2000.

34. Chittenden T, Harrington EA, O'Connor R, Flemington C, Lutz RJ, Evan GI and Guild BC: Induction of apoptosis by the Bcl-2 homologue Bak. Nature 374: 733-736, 1995.
35. Farrow SN, White JH, Martinou I, Raven T, Pun KT, Grinham CJ, Martinou JC and Brown R: Cloning of a bcl-2 homologue by interaction with adenovirus E1B 19K. Nature 374: 731-733, 1995

36. Kiefer MC, Brauer MJ, Powers VC, Wu JJ, Umansky SR, Tomei LD and Barr PJ: Modulation of apoptosis by the widely distributed Bcl-2 homologue Bak. Nature 374: 736-739, 1995.

37. Clemmons DR, Camacho-Hubner C, Coronado E and Osborne CK: Insulin-like growth factor binding protein secretion by breast carcinoma cell lines: correlation with estrogen receptor status. Endocrinology 127: 2679-2686, 1990.

38. Pekonen F, Nyman T, Ilvesmöki V and Partanen S: Insulin-like growth factor binding proteins in human breast cancer tissue. Cancer Res 52: 5204-5207, 1992.

39. Pistritto G, Jost M, Srinivasula SM, Baffa R, Poyet JL, Kari C, Lazebnik Y, Rodeck U and Alnemri ES: Expression and transcriptional regulation of caspase-14 in simple and complex epithelia. Cell Death Differ 9: 995-1006, 2002.

40. Jurianz K, Ziegler S, Garcia-Schüler H, Kraus S, Bohana-Kashtan O, Fishelson Z and Kirschfink M: Complement resistance of tumor cells: basal and induced mechanisms. Mol Immunol 36: 929-939, 1999.

41. Sugimoto M, Nakamura T, Ohtani N, Hampson L, Hampson IN Shimamoto A, Furuichi Y, Okumura K, Niwa S, Taya Y and Hara E: Regulation of CDK4 activity by a novel CDK4-binding protein, p34 (SEI-1). Genes Dev 13: 3027-3033, 1999.

42. Herbert BR, Sanchez J-C, Bini L, Wilkins MR, Williams KL, Appel RD and Hochstrasser DF (eds.): Proteome Research: New Frontiers in Functional Genomics. Springer Berlin pp13-33, 1997.

43. Sherr CJ and Roberts JM: CDK inhibitors: positive and negative regulators of G1-phase progression. Genes Dev 13: 1501-1512, 1999.

44. Bartek J, Bartkova J and Lukas J: The retinoblastoma protein pathway in cell cycle control and cancer. Exp Cell Res 237: 1-6, 1997. 